\title{
Collagen and Glycosaminoglycan Profiles in the Canine Cervix during Different Stages of the Estrous Cycle and in Open- and Closed-Cervix Pyometra
}

\author{
Pichanun LINHARATTANARUKSA ${ }^{1)}$, Sayamon SRISUWATANASAGUL ${ }^{2)}$, Suppawiwat PONGLOWHAPAN ${ }^{1}$, \\ Muhammad KHALID ${ }^{3)}$ and Kaywalee CHATDARONG ${ }^{1) *}$ \\ ${ }^{1)}$ Department of Obstetrics, Gynaecology and Reproduction, Faculty of Veterinary Science, Chulalongkorn University, Bangkok 10330, \\ Thailand \\ ${ }^{2)}$ Department of Anatomy, Faculty of Veterinary Science, Chulalongkorn University, Bangkok 10330, Thailand \\ ${ }^{3)}$ Department of Veterinary Clinical Sciences, The Royal Veterinary College, University of London, Hawkshead Lane, North Mymms, \\ Hatfield, Hertfordshire, AL9 7TA, U.K.
}

(Received 3 March 2013/Accepted 4 October 2013/Published online in J-STAGE 22 October 2013)

ABSTRACT. The extracellular matrix of the cervix that comprises collagen, elastin, proteoglycans and glycosaminoglycans (GAGs) is thought to have an essential role in cervical relaxation. This study investigated the proportion of collagen and smooth muscle as well as the GAGs in cervices obtained from healthy bitches at different stages of the estrous cycle and bitches with open- and closed-cervix pyometra. Cervices were collected after ovariohysterectomy. The proportion of collagen to smooth muscle was determined using Masson's trichrome staining. Alcian blue staining was used to evaluate the relative distribution of cervical GAGs. The proportion of cervical collagen relative to smooth muscle was higher at estrus compared to anestrus $(P \leq 0.05)$. It was also higher $(P \leq 0.05)$ in bitches with open- compared to those with closedcervix pyometra. Overall, hyaluronan (HA) was the predominant GAG in the canine cervix. In the luminal epithelium, the staining intensity for HA was stronger in estrus than in anestrus $(P \leq 0.05)$, but not in diestrus $(P>0.05)$. On the contrary, the intensity for the combined keratan sulfate (KS) and heparan sulfate (HS) was stronger in anestrus than in estrus and diestrus $(P \leq 0.05)$. In bitches with pyometra, the staining intensity of the stroma for KS and HS was weaker in open- compared to closed-cervix pyometra $(P \leq 0.05)$. Collectively, the different profiles of collagen and GAG suggest that the metabolism of both collagen and GAGs in the canine cervix is associated with hormonal statuses during the estrous cycle and cervical patency of bitches with pathological uterine conditions, such as pyometra.

KEY WORDS: canine, cervix, extracellular matrix.

doi: 10.1292/jvms.13-0114; J. Vet. Med. Sci. 76(2): 197-203, 2014

The cervix has a crucial role during the reproductive cycle, and the consistency of the cervix varies according to the stages of the estrous cycle. It is dilated during the estrous stage and closed during the anestrous and diestrous stages. In cows and mares [1], the cervix is softer at estrus compared to its consistency in the luteal phase, whereas in sows [19] and bitches [27], it is firmer at estrus compared to that at diestrus.

The cervix is mainly composed of connective tissue and smooth muscle, supported by extracellular matrix (ECM). The ECM is a network composed of collagen bundles, glycoproteins, proteoglycans, glycosaminoglycans (GAGs) and water [7]. Among those, collagen is the most abundant protein in the ECM which provides structural support [11, 17]. Cervical relaxation is mediated by the reorganization of collagen bundles and decrease in the concentration of collagen [6]. The fact that estradiol can induce collagen remodelling in the cervix of the pregnant ewe suggests that the ovarian steroid hormones have effects on cervical

*Correspondence to: Chatdarong, K., Department of Obstetrics, Gynaecology and Reproduction, Faculty of Veterinary Science, Chulalongkorn University, Bangkok 10330, Thailand.

e-mail: Kaywalee.C@chula.ac.th

C2014 The Japanese Society of Veterinary Science

This is an open-access article distributed under the terms of the Creative Commons Attribution Non-Commercial No Derivatives (by-nc-nd) License $<$ http://creativecommons.org/licenses/by-nc-nd/3.0/>. function [22]. During estrus, the bovine cervix relaxes, accompanied by an increase in its water content [32]. The polymeric GAGs are made up of repeating disaccharides to form a family of related molecular species. They are classified into two groups; sulfated and non-sulfated. The sulfated GAGs (S-GAGs) are chondroitin sulfate (CS), dermatan sulfate (DS), keratan sulfate (KS) and heparan sulfate (HS), and the non-sulfated GAG is hyaluronan (HA) or hyaluronic acid. The major GAGs present in the human cervix are CS, DS and HA, although KS and HS are also found to a lesser extent. The content of HA, a hydrophilic GAG, is thought to influence cervical hydration [29]. The prominent changes in human cervix observed during the peri-ovulatory phase are an increase in the total GAG and HA, but a decrease in sulfated GAGs (DS and CS) [37]. However, until present, no data have been reported regarding the composition of the GAGs in the canine cervix.

In the bitch, alterations in cervical relaxation are observed not only during the estrous cycle but also in some pathological conditions of the uterus, such as pyometra. There are two types of pyometra defined by cervical patency; they are open-cervix pyometra and closed-cervix pyometra. To date, the mechanism of cervical relaxation in the bitch remains poorly understood in both physiological (estrous cycle) and pathological (pyometra) conditions. Our previous study demonstrated a higher infiltration of neutrophils in the cervix of bitches with open- compared to closed-cervix pyometra [18], 
Table 1. Criteria for estrous cycle staging in healthy bitches

\begin{tabular}{|c|c|c|c|c|}
\hline $\begin{array}{l}\text { Stage of estrous } \\
\text { cycle }\end{array}$ & $\begin{array}{l}\text { Majority of vaginal } \\
\text { epithelial cells }\end{array}$ & Ovarian structure & $\begin{array}{l}\text { Progesterone concentration } \\
(n \mathrm{~g} / \mathrm{m} l)(\text { Mean } \pm \mathrm{SD}) \text { (Range) }\end{array}$ & Uterine histology \\
\hline Anestrus & Basal cells & Quiescent & $0.5 \pm 0.4(0.1-1.2)$ & Inactive phase \\
\hline Estrus & Cornified cells & $\begin{array}{l}\text { Large follicles }(>0.5 \mathrm{~cm}) \text { and } \\
\text { corpora hemorrhagica }\end{array}$ & $5.1 \pm 2.9(1.1-8.9)$ & Proliferative to early secretory stage \\
\hline Diestrus & Non-cornified cells & $\begin{array}{l}\text { Corpora lutea }(>0.5 \mathrm{~cm}) \text { and/ } \\
\text { or corpora hemorrhagica }\end{array}$ & $12.8 \pm 10.0(1.3-37.8)$ & Secretory stage \\
\hline
\end{tabular}

and involvement of interleukin- 8 expression in the increased cervical patency was suggested [30]. In addition, increased infiltration of mast cells and macrophages was observed in the cervical stroma during estrus [13], and in women, cervical polymorphonuclear cells were increased during parturition [25]. Although cytokines released from neutrophils in the cervical stroma decreased collagen and increased GAG content [4] in the cervix, the effect of stromal neutrophils on cervical patency in bitches having open-cervix pyometra requires investigation.

Because as shown for the ewe, the proportion of collagen to smooth muscle [15] as well as the changes in GAG distribution [14] is an important determinant of the structural integrity of the cervix that relates closely to cervical function, we hypothesized that the hormonal changes during the reproductive cycle of the bitch also regulates cervical function by remodeling collagen to alter the properties of cervical smooth muscle and GAG distribution; moreover, the proportion of collagen to smooth muscle and GAG distribution also differ between open- and closed-cervix pyometra. The aims of this study were to determine the proportion of collagen and smooth muscle as well as the proportions of the different GAGs in the cervix of healthy bitches at different stages of the estrous cycle and in bitches with either open- or closed-cervix pyometra.

\section{MATERIALS AND METHODS}

Experimental design: The study was performed in two parts. In Part I, sections of cervix were stained for collagen and smooth muscle using Masson's trichrome and determined by computerized image analysis. Part II determined the types and proportions of cervical GAGs using Alcian blue 8GX staining. Cervical tissue was obtained from healthy cyclic bitches and bitches with pyometra. Healthy bitches were grouped according to the stage of their estrous cycle, and bitches with pyometra were classified as open- or closed-cervix.

Animals: Twenty eight healthy cyclic bitches of various breeds were used in the study. The average age was $2.1 \pm 0.8$ years (mean \pm SEM, range $1-4$ years). At the time of ovariohysterectomy, 10 bitches were classified as in anestrus, 7 in estrus and 11 in diestrus. Another group of 28 bitches with pyometra (open-cervix, $n=18$; closed-cervix, $n=10$ ) and a mean age of $7.0 \pm 3.9$ years (range, $2-15$ years) were also included.

The stages of the estrous cycle were initially sorted by the reproductive history, vaginal cytology, ovarian morphology (i.e., number and size of follicles, corpora hemorrhagica and corpora lutea), combined with serum progesterone concentrations and histology of hematoxylin-eosin stained sections of the uterine part of the cervix (Table 1). A diagnosis of pyometra was based on clinical signs, hematology and an ultrasound scan of the uterus. Open- and closed-cervix pyometra were classified according to the presence or absence of purulent vulvar discharge, respectively.

Collection and processing of samples: Cervical tissue samples were collected surgically and prepared as previously described [18]. Briefly, the cervix was longitudinally cut from the internal to external os, fixed in 4\% paraformaldehyde for $36-48 \mathrm{hr}$ and embedded in paraffin wax. Samples were sectioned at $4 \mu \mathrm{m}$ and then placed on coated slides (3-aminopropyl-triethoxysilane, minimum 98\%; SigmaAldrich, Taufkirchen, Germany) for Masson's trichrome or Alcian blue staining.

Hormone analyses: Blood samples were collected from the cephalic vein by venipuncture; serum was separated and stored at $-20^{\circ} \mathrm{C}$. Progesterone concentrations were determined using a luminescence immunoassay (Immulite Progesterone, Diagnostic Products, Los Angeles, CA, U.S.A.). The intra-assay coefficients of variation were $3.9 \%$ at $0.1 \mathrm{ng} /$ $\mathrm{m} l$ and $6.5 \%$ at $36.1 \mathrm{ng} / \mathrm{ml}$. The inter-assay coefficients of variation were $3.8 \%$ at $0.1 \mathrm{ng} / \mathrm{ml}$ and $16.3 \%$ at $36.1 \mathrm{ng} / \mathrm{ml}$. The minimal assay sensitivity was $0.04 \mathrm{ng} / \mathrm{m} \mathrm{l}$.

Staining with Masson's trichrome and the determination of collagen and smooth muscle areas: To determine the proportion of collagen to smooth muscle, tissue sections were deparaffinized, rehydrated with graded alcohols, immersed in warm Bouin's solution (Sigma-Aldrich, St. Louis, MO, U.S.A.) $\left(55-60^{\circ} \mathrm{C}\right)$ for $2 \mathrm{hr}$ and washed in running tap water for $2 \mathrm{~min}$ followed by distilled water for 30-60 sec. Thereafter, they were stained with Weigert Hematoxylin (Merck, Darmstadt, Germany) for 10 min and rinsed until only the cell nuclei were stained. Smooth muscle was stained red with Biebrich Scarlet-Acid-Fuschin (Sigma-Aldrich) for $10 \mathrm{~min}$, rinsed and immersed in phosphomolybdic phosphotungstic acid (Sigma-Aldrich) for $15 \mathrm{~min}$. Subsequently, collagen was stained blue with Aniline Blue (Sigma-Aldrich) for 10 min and rinsed in distilled water followed by immersion in $1 \%$ acetic acid for $5 \mathrm{~min}$. Finally, the tissues were rehydrated with 95 and $100 \%$ ethanol, left to air dry and mounted with mounting medium. All sections of cervical tissue were stained at the same time.

Color image analysis was performed under a light microscope at $40 \times$ magnification. A total of 5 to 10 reading fields were taken from each cervical section to cover the entire 
section. The blue (collagen) and red (muscle) stained area of the cervical tissue was measured using a software program (Image-Pro PLUS 6.0, Media Cybernetics, Inc., Rockville, MD, U.S.A.). Proportion of collagen and muscle was calculated by the number of pixels of either blue (collagen) or red (muscle) color using an automated detection system, producing a percentage area for collagen and muscle in a tissue section. According to the lack of collagen in the luminal epithelium, the proportion of collagen to smooth muscle was evaluated only in the two tissue layers, e.g. stroma and muscle. The mean proportion of collagen and muscle and standard errors of means were calculated from 5 to 10 readings per section.

Staining with Alcian blue $8 G X$ and the determination of GAGs: Tissue GAGs were determined by Alcian blue staining as previously described $[14,23]$. Briefly, tissue sections were de-waxed, rehydrated and immersed in $0.025 \mathrm{M}$ so-

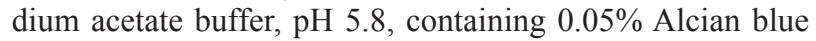
8GX (Sigma, Poole, U.K.) with different concentrations of $\mathrm{MgCl}_{2}(0.05 \mathrm{M}, 0.4 \mathrm{M}$ and $0.8 \mathrm{M})$ for $18 \mathrm{hr}$ at room temperature. Sections were washed three times in the corresponding buffer containing $\mathrm{MgCl}_{2}$, dehydrated and mounted in DPX.

Alcian blue stains different types of GAGs at different concentrations of $\mathrm{MgCl}_{2}$ [23]. At low concentrations (0.05 $\mathrm{M} \mathrm{MgCl}_{2}$ ), all GAGs stain; at $0.4 \mathrm{M} \mathrm{MgCl}_{2}$, all the sulfated GAGs (chondroitin sulfate, CS; dermatan sulfate, DS; heparan sulfate, $\mathrm{HS}$; and keratan sulfate, $\mathrm{KS}$ ) stain and at $0.8 \mathrm{M}$ $\mathrm{MgCl}_{2}$ only highly sulfated GAGs (KS and HS) stain.

Three cervical cell layers, i.e. luminal epithelium, stroma and muscle, were separately analyzed for the intensity of staining with Alcian blue using a Vickers M85A scanning and integrating microdensitometer [14]. Ten readings of each cell layer at each concentration of $\mathrm{MgCl}_{2}$ were taken at 550 $\mathrm{nm}$. Absolute Alcian blue staining intensity was expressed as the mean integrated extinction $(\mathrm{MIE} \times 100)$ per unit area. The calculation of MIE of all GAGs in each layer was performed as previously described [14]. In brief, the percentage of sulfated GAGs (CS, DS, KS and HS) was subtracted from the percentage of total GAGs (taken as $100 \%$ ) to determine the percentage of non-sulfated GAGs (i.e. hyaluronan; HA). Similarly, percentage of highly sulfated GAGs (KS and HS) was subtracted from that for all the sulfated GAGs to determine the percentages of CS and DS and KS and HS. Results are expressed as (i) total GAGs, (ii) percentage of HA, (iii) percentage of total sulfated GAGs, (iv) percentage of CS plus DS and (v) percentage of KS plus HS [14].

Statistical analysis: Data on the proportions of smooth muscle and collagen and the percentages of GAGs were analyzed to compare the effect of the stage of the estrous cycle by an analysis of variance using SPSS version 13.0 (SPSS Inc., Chicago, IL, U.S.A.). The Bonferroni test was performed for subsequent post hoc paired comparisons. The $t$-test was for animals with open-cervix or closed-cervix pyometra comparing the proportions of smooth muscle and collagen and the percentages of GAGs between these two conditions. Level of significance was set at $P \leq 0.05$.

\section{RESULTS}

Proportion of collagen and smooth muscle: Examples of the blue-stained collagen and red-stained smooth muscle in the cervix of a cyclic bitch and a bitch with pyometra are shown in Fig. 1. As the technique used in this study determined the relative area of collagen to smooth muscle, the area of collagen was in an inverse relationship with the area of smooth muscle. Overall, the relative area occupied by collagen was lower $(P \leq 0.05)$ during anestrus compared to estrus, but did not differ between anestrus and diestrus $(P>0.05$, Table 2). A higher proportion of collagen proportion was found in the cervical tissue of bitches with opencompared to closed-cervix pyometra $(P \leq 0.05$, Table 2$)$.

Glycosaminoglycans: The pattern of staining with Alcian blue at 3 concentrations of $\mathrm{MgCl}_{2}$ for 3 groups of GAGs; non-sulfated GAGs (mainly HA), sulfated GAGs (CS plus DS) and highly sulfated GAGs (KS plus HS) are shown in Fig. 2. Regardless of GAG type, the GAGs were primarily confined to the smooth muscle layers (Tables 3 and 4). The total GAGs in the cervix occupied about $46.8 \%$ of the muscle layer, $23.4 \%$ of the luminal epithelium and $28 \%$ of the stroma. Hyaluronan was the predominant GAG not only in the cervix of healthy bitches, irrespective of the stage of estrous cycle, but also in bitches with pyometra (Tables 3 and 4). In the luminal epithelium and muscle layers, HA was the predominant GAG ( $69.0 \%$ of total GAGs). In the stroma, the percentage of HA was $47.5 \%$ of the total.

In the luminal epithelium of healthy bitches, HA and KS plus HS were both significantly $(P \leq 0.05)$ higher in estrus than anestrus (Table 3 ). In the muscle layer, CS plus DS were higher $(P \leq 0.05)$ in estrus than diestrus. However, no significant differences were observed among the stages of the estrous cycle in the stroma of healthy bitches (Table 3 ).

In bitches with pyometra, all types of GAGs in the luminal epithelium and muscle layers were not different between open- and closed-cervix pyometra. However, in stroma, the KS plus HS were higher $(P \leq 0.05)$ in cervices from closedcompared to open-cervix pyometra (Table 4).

\section{DISCUSSION}

The results of this study demonstrated that proportion of collagen to smooth muscle and GAG components in the cervix of healthy intact bitches differed according to the stage of the estrous cycle, i.e. estrus, diestrus and anestrus, suggesting an influence of sex steroids on the ECM of the canine cervix. In bitches with pyometra, the proportion of collagen was higher in those with open-cervix pyometra, but the GAGs did not differ between open- and closed-cervix pyometra, except for the highly sulfated GAGs, KS plus HS, in stroma where it was higher in cervical tissues from bitches with closed-cervix pyometra. These findings suggest that mechanisms regulating cervical patency in pyometra have a greater impact on collagen remodeling rather than on the patterns of GAGs.

In line with a recent study on the sheep cervix, the increase in cervical area occupied by collagen during estrus 

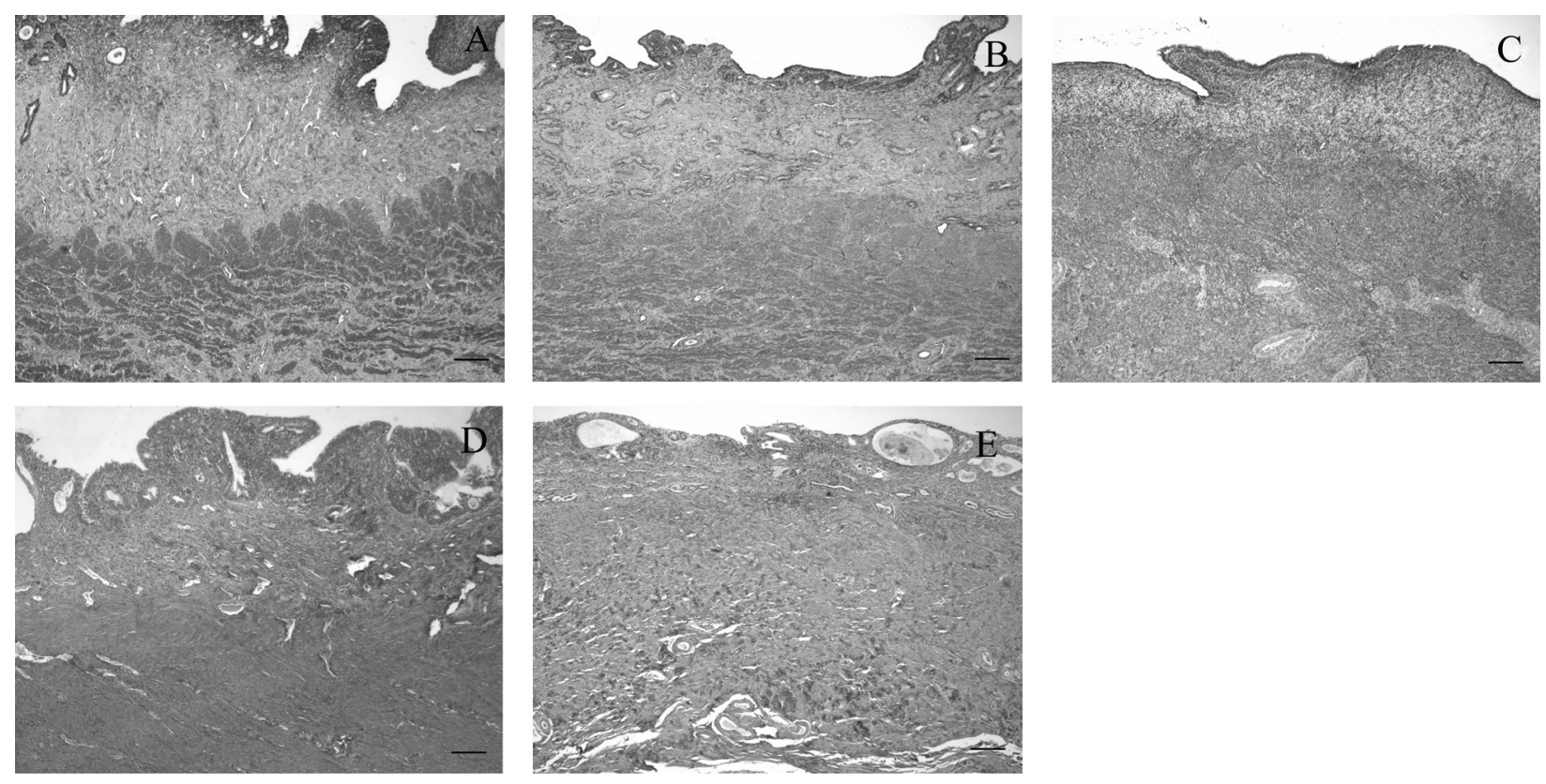

Fig. 1. Masson's trichrome staining for blue-stained collagen and red-counterstained smooth muscle in the cervix of healthy bitches at estrus (A), diestrus (B), anestrus (C) and in bitches with open-cervix (D) and closed-cervix pyometra (E). Bar=100 $\mu \mathrm{M}$.
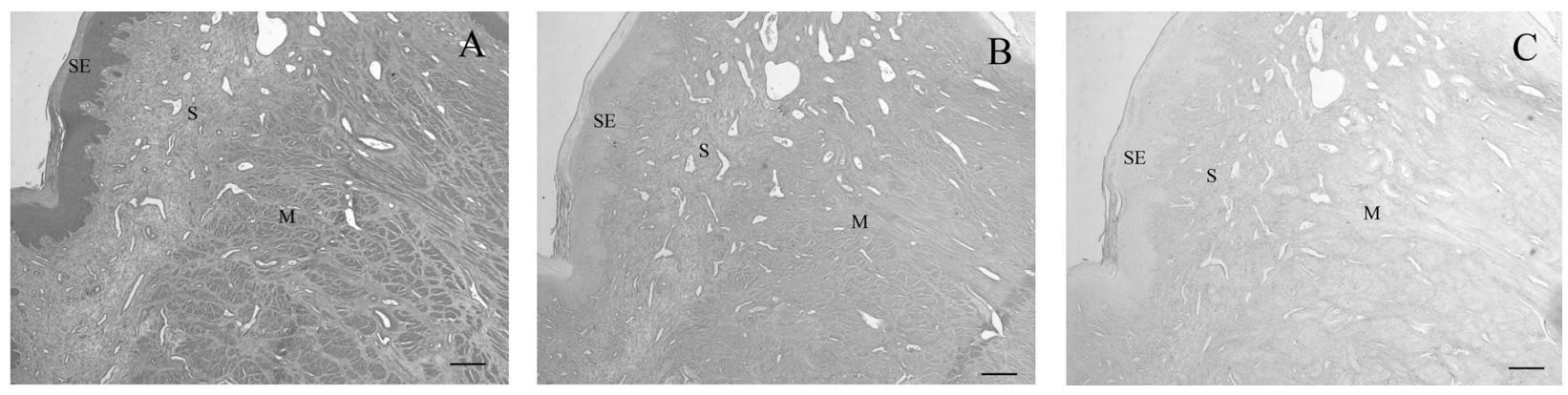

Fig. 2. Alcian blue staining in body of the cervical tissue (A-C) of an anestrous bitch. Differences in staining intensity among the 3 varying concentrations of $\mathrm{MgCl}_{2}$ can be noted; total GAGs at $0.05 \mathrm{MgCl}_{2}$ (A), total sulfated GAGs at $0.4 \mathrm{MgCl}_{2}$ (B) and highly sulfated GAGs at 0.8 $\mathrm{MgCl}_{2}$ (C). Cervical cell layers are labeled: luminal epithelium (LE), stroma (S) and smooth muscle (M). Bar=100 $\mu \mathrm{M}$.

Table 2. Proportion (\%) of collagen in relative to smooth muscle (mean $\pm \mathrm{SEM})$ in the cervices of bitches during different stages of the estrous cycle and with open- and closed-cervix pyometra

\begin{tabular}{llrl}
\hline Status of bitches & & $\mathrm{n}$ & \% collagen \\
\hline Healthy & Anestrus & 10 & $47.03 \pm 2.50^{\mathrm{a})}$ \\
& Estrus & 7 & $57.87 \pm 2.39^{\mathrm{b})}$ \\
& Diestrus & 11 & $\left.50.89 \pm 2.14^{\mathrm{a}, \mathrm{b}}\right)$ \\
\hline Pyometra & Open-cervix & 18 & $39.57 \pm 1.67^{\mathrm{x})}$ \\
& Closed-cervix & 8 & $26.49 \pm 2.23^{\mathrm{y})}$ \\
\hline
\end{tabular}

Values with different superscripts within healthy bitches (a and b) and bitches with pyometra ( $\mathrm{x}$ and $\mathrm{y})$ differed significantly $(P \leq 0.05)$. observed in the present study appeared to be associated with high estradiol concentrations [15]. It has been suggested that the ovarian steroid hormones have a role in the synthesis and remodeling of collagen in the uterus of the rabbit [10], the uterine cervix of women [34] and the cervix of the ewe [15] and the lower urinary tract of the dog [24]. Moreover, the estradiol-induced disruption of collagen bundles has been demonstrated in the cervix of pregnant [22] and estrus [38] ewes. Our results were also in line with the previous report, demonstrating the decreased collagen concentration and increased collagenase activity in relation to cervical relaxation in the bitches with pyometra [30]. The disruption of collagen bundles in this study could be characterized by the increased interfibrillary distance of collagen fibrils likely due to increased water content in the cervical tissue $[2,6]$. In this study, the proportions of collagen and smooth muscle 
Table 3. Intensity of glycosaminoglycan (GAG) staining (MIE \pm SEM) in different tissue layers of the bitch cervix during different stages of the estrous cycle

\begin{tabular}{|c|c|c|c|}
\hline $\begin{array}{l}\text { Stage of estrous } \\
\text { cycle }\end{array}$ & $\begin{array}{l}\text { Luminal epi- } \\
\text { thelium }\end{array}$ & Stroma & Muscle \\
\hline \multicolumn{4}{|l|}{ Total GAGs } \\
\hline Anestrus & $10.58 \pm 1.09^{\mathrm{a})}$ & $6.79 \pm 0.56^{\mathrm{a})}$ & $16.50 \pm 2.23^{\mathrm{a})}$ \\
\hline Estrus & $15.84 \pm 2.09^{b)}$ & $7.13 \pm 0.50^{\mathrm{a})}$ & $19.31 \pm 1.83^{\mathrm{a})}$ \\
\hline Diestrus & $14.06 \pm 1.73^{\mathrm{a}, \mathrm{b})}$ & $6.30 \pm 0.63^{\mathrm{a})}$ & $17.53 \pm 1.67^{\mathrm{a})}$ \\
\hline \multicolumn{4}{|l|}{ Hyaluronan (HA) } \\
\hline Anestrus & $7.31 \pm 1.30^{\mathrm{a})}$ & $3.23 \pm 0.54^{\mathrm{a})}$ & $10.27 \pm 2.29^{\mathrm{a})}$ \\
\hline Estrus & $12.80 \pm 2.30^{b)}$ & $3.24 \pm 0.67^{\mathrm{a})}$ & $12.15 \pm 2.19^{a)}$ \\
\hline Diestrus & $10.68 \pm 1.61^{\mathrm{a}, \mathrm{b})}$ & $3.09 \pm 0.59^{a)}$ & $11.89 \pm 1.55^{\mathrm{a})}$ \\
\hline \multicolumn{4}{|c|}{ Total sulfated GAGs } \\
\hline Anestrus & $3.26 \pm 0.27^{\mathrm{a})}$ & $3.56 \pm 0.28^{a)}$ & $6.23 \pm 0.26^{a)}$ \\
\hline Estrus & $3.04 \pm 0.31^{\mathrm{a})}$ & $3.88 \pm 0.33^{a)}$ & $7.15 \pm 0.94^{a)}$ \\
\hline Diestrus & $3.38 \pm 0.45^{\mathrm{a})}$ & $3.21 \pm 0.41^{\mathrm{a})}$ & $5.64 \pm 0.56^{\mathrm{a})}$ \\
\hline \multicolumn{4}{|c|}{ Chondroitin sulfate and dermatan sulfate (CS and DS) } \\
\hline Anestrus & $2.02 \pm 0.24^{\mathrm{a})}$ & $2.06 \pm 0.14^{\mathrm{a})}$ & $4.52 \pm 0.22^{\mathrm{a}, \mathrm{b})}$ \\
\hline Estrus & $2.30 \pm 0.31^{\mathrm{a})}$ & $2.43 \pm 0.27^{\mathrm{a})}$ & $5.56 \pm 0.83^{\mathrm{a})}$ \\
\hline Diestrus & $2.53 \pm 0.39^{\mathrm{a})}$ & $1.85 \pm 0.33^{\mathrm{a})}$ & $3.80 \pm 0.41^{\mathrm{b})}$ \\
\hline \multicolumn{4}{|c|}{ Keratan sulfate and Heparan sulfate (KS and HS) } \\
\hline Anestrus & $1.24 \pm 0.14^{\mathrm{a})}$ & $1.53 \pm 0.26^{\mathrm{a})}$ & $1.71 \pm 0.22^{\mathrm{a})}$ \\
\hline Estrus & $0.74 \pm 0.0 .8^{\mathrm{b})}$ & $1.45 \pm 0.15^{\mathrm{a})}$ & $1.59 \pm 0.18^{\mathrm{a})}$ \\
\hline Diestrus & $0.84 \pm 0.09^{\mathrm{b})}$ & $1.35 \pm 0.21^{\mathrm{a})}$ & $1.77 \pm 0.23^{\mathrm{a})}$ \\
\hline
\end{tabular}

Within columns, values with different superscripts (a and b) differed significantly $(P \leq 0.05)$.

differed among estrus, diestrus and anestrus, suggesting an influence of hormonal status on collagen remodeling. However, the involvement of collagen in cervical patency (open versus closed) in the dog remained an interesting subject for further investigation. In this respect, it would be interesting to compare samples of cervix taken from estrous bitches when the cervix is open, approximately 2 days before the $\mathrm{LH}$ surge, or closed, 3 days before end of the estrus [27], including cervical tissue from pregnant and peripartum bitches.

The bitches affected with open-cervix pyometra had increased proportion of collagen area in the cervix, in other words, a decreased proportion of smooth muscle, suggesting disruption of collagen leading to cervical relaxation (opening). This phenomenon associated with an inflammatory reaction in the uterus and also in the cervix as evidenced by the higher degree of neutrophil infiltration in cervical tissues of bitches with open-cervix pyometra [18]. The loosening of collagen in the cervix is characterized by a decrease in GAG-protein interactions probably induced by collagenolytic enzymes, such as the matrix metalloproteinases (MMPs) from cervical neutrophils [26]. Although the exact underlying mechanism (s) that alter cervical patency in bitches with pyometra is still unclear, neutrophils that induce collagenolytic enzymes and other cytokines are likely participants. To our knowledge, the GAGs in the canine cervix have not been reported previously. This study revealed variation in distribution of the various GAGs among the tissue layers (luminal epithelium, stroma and muscle) of the cervix. The findings that HA, the predominant GAG, was more abundant
Table 4. Intensity of glycosaminoglycan (GAG) staining (MIE \pm SEM) in different tissue layers of the cervices of bitches with open- and closed-cervix pyometra

\begin{tabular}{|c|c|c|c|}
\hline Status of pyometra & $\begin{array}{l}\text { Luminal epi- } \\
\text { thelium }\end{array}$ & Stroma & Muscle \\
\hline \multicolumn{4}{|l|}{ Total GAGs } \\
\hline Opn & $12.97 \pm 1.13^{\mathrm{a})}$ & $8.31 \pm 0.57^{\mathrm{a})}$ & $20.92 \pm 1.58^{a)}$ \\
\hline Closed & $12.07 \pm 1.65^{\mathrm{a})}$ & $8.30 \pm 1.11^{\mathrm{a})}$ & $19.54 \pm 2.50^{\mathrm{a})}$ \\
\hline \multicolumn{4}{|l|}{ Hyaluronan (HA) } \\
\hline Open & $9.73 \pm 1.16^{\mathrm{a})}$ & $4.21 \pm 0.53^{\mathrm{a})}$ & $14.85 \pm 1.62^{\mathrm{a})}$ \\
\hline Closed & $8.48 \pm 1.72^{\mathrm{a})}$ & $4.01 \pm 1.12^{\mathrm{a})}$ & $13.37 \pm 2.4^{\mathrm{a})}$ \\
\hline \multicolumn{4}{|l|}{ Total Sulfated GAGs } \\
\hline Open & $3.23 \pm 0.19^{\mathrm{a})}$ & $4.09 \pm 0.18^{\mathrm{a})}$ & $6.07 \pm 0.25^{\mathrm{a})}$ \\
\hline Closed & $3.58 \pm 0.27^{\mathrm{a})}$ & $4.29 \pm 0.36^{\mathrm{a})}$ & $6.17 \pm 0.50^{\mathrm{a})}$ \\
\hline \multicolumn{4}{|c|}{ Chondroitin sulfate and dermatan sulfate (CS and DS) } \\
\hline Open & $2.34 \pm 0.18^{\mathrm{a})}$ & $2.90 \pm 0.17^{\mathrm{a})}$ & $4.40 \pm 0.21^{\text {a) }}$ \\
\hline Closed & $2.45 \pm 0.21^{\mathrm{a})}$ & $2.38 \pm 0.27^{\mathrm{a})}$ & $4.04 \pm 0.61^{\mathrm{a})}$ \\
\hline \multicolumn{4}{|c|}{ Keratan sulfate and Heparan sulfate (KS and HS) } \\
\hline Open & $0.89 \pm 0.12^{\mathrm{a})}$ & $1.18 \pm 0.10^{\mathrm{a})}$ & $1.66 \pm 0.17^{\mathrm{a})}$ \\
\hline Closed & $1.13 \pm 0.17^{\mathrm{a})}$ & $1.90 \pm 0.28^{b)}$ & $2.12 \pm 0.19^{\mathrm{a})}$ \\
\hline
\end{tabular}

Within columns, values with different superscripts ( $\mathrm{a}$ and $\mathrm{b}$ ) differed significantly $(P \leq 0.05)$.

in the muscle layers than in the luminal epithelium or the stroma were in agreement with findings in the sheep cervix $[8,14]$. Our results in the cyclic bitches are also in line with a previous report for sheep showing that cervical HA was highest during estrus compared to other stages of the cycle [19]. Hyaluronan has hydrophilic properties which cause tissue edema, dissociation of collagen fibers and decreased extensibility of cervical tissue, all of which assist cervical ripening/relaxation $[9,34]$. In the cyclic bitches, increased HA in the luminal epithelium during estrus was likely related to high estradiol concentrations. Studies in human cervical tissues support this notion that estradiol positively regulates HA synthesis in the cervix [31] while progesterone has the opposite (inhibitory) effect on HA synthesis [33]. HA is involved in inflammatory processes and is ultimately linked to inflammatory cytokines. The local application of HA to the rabbit cervix resulted in a higher number of neutrophils that produce MMPs and thus regulate the remodeling collagen and facilitate cervical ripening [5]. In cyclic bitches, during estrus, HA was increased, whereas the number of neutrophils was not [18]. In pyometra bitches, there was no difference in HA between open- and closed-cervix pyometra, although there was an increased density of neutrophils in the bitches with open-cervix pyometra [18]. Taken together, these findings suggest different regulatory roles of HA and/or neutrophils in regulating cervical ECM and cervical patency in normal cyclic bitches and bitches with pyometra.

Similar to our findings, the 4 sulfated GAGs, CS, DS, KS and HS, are present in human [3, 16, 20, 34] and rat [21] cervical tissues. However, no CS is detected in the sheep cervix [19], and thus, the cervical distribution of GAGs may vary according to the species. Because sulfated GAGs increase the strength of electrostatic interactions between collagen fibers and the binding of DS to collagen [20], a reduction 
in sulfated GAGs may weaken the cross-links between collagen fibers [35]. These observations support our findings of significantly lower concentrations of the highly sulfated GAGs (KS and HS) in the cervical stroma of bitches with open-cervix pyometra. Furthermore, HS regulated leukocytic infiltration [28], and in genetically-modified mice lacking HS, increased leukocyte recruitment was reported in cardiac muscle [36]. The lower combined amount of HS and KS and increased neutrophil density observed in bitches with open-cervix pyometra may act to re-arrange collagen, thus weakening it and causing cervical relaxation [12].

In conclusion, the results of this study have demonstrated that (i) the proportion of collagen to smooth muscle altered depending on stages of the estrous cycle and suggest that such changes are related to the milieu of ovarian hormones, (ii) a higher proportion of collagen was found in bitches with open-cervix pyometra where the cervix was fully relax and a lower proportion of collagen was found in cases of closedcervix pyometra where the cervix was tightly closed, indicating different structural function of cervical collagen in dogs with a uterine pathology and (iii) the distribution of cervical GAGs varied among tissue layers of the canine cervix, the stages of the estrous cycle and between open- closed-cervix pyometra. HA, the predominant cervical GAG, may have a role in remodeling collagen and in cervical relaxation via either an increase in the water content of the tissue or by acting in conjunction with tissue cytokines. It is interesting to note that our results suggest that HA is not involved in the patency of the cervix in bitches with pyometra, but that the highly sulfated GAGs (KS and HS) along with cytokines produced by local neutrophils seem to be responsible.

ACKNOWLEDGMENTS. The study was supported financially by the Royal Thai Golden Jubilee (RGJ) Ph.D. program, the Thailand Research Fund, the Project Research Fund and the Research Unit for Obstetrics and Reproduction in Animals at Faculty of Veterinary Science, Chulalongkorn University. The authors thank Em.Prof. RJ Scaramuzzi for assistance on linguistic correction.

\section{REFERENCES}

1. Blandau, R. J. and Moghissi, K. 1973. The comparative anatomy of the mammalian cervix. pp. 22-56. In: The Biology of the Cervix, (Hafez, E. S. E. ed.), University of Chicago, Chicago.

2. Breeveld-Dwarkasing, V. N. A., te Koppele, J. M., Bank, R. A., van der Weijden, G. C., Taverne, M. A. M. and van Dissel-Emiliani, F. M. F. 2003. Changes in water content, collagen degradation, collagen content, and concentration in repeated biopsies of the cervix of pregnant cows. Biol. Reprod. 69: 1608-1614. [Medline] [CrossRef]

3. Cabrol, D., Breton, M., Berrou, E., Visser, A., Sureau, C. and Picard, J. 1980. Variations in the distribution of glycosaminoglycans in the uterine cervix of the pregnant woman. Eur. J. Obstet. Gynecol. Reprod. Biol. 10: 281-287. [Medline] [CrossRef]

4. el Maradny, E., Kanayama, N., Halim, A., Maehara, K., Sumimoto, K. and Terao, T. 1994. Interleukin-8 induces cervical ripening in rabbits. Am. J. Obstet. Gynecol. 171: 77-83. [Medline] [CrossRef]
5. El Maradny, E., Kanayama, N., Kobayashi, H., Hossain, B., Khatun, S., Liping, S., Kobayashi, T. and Terao, T. 1997. The role of hyaluronic acid as a mediator and regulator of cervical ripening. Hum. Reprod. 12: 1080-1088. [Medline] [CrossRef]

6. Feltovich, H., Ji, H., Janowski, J. W., Delance, N. C., Moran, C. C. and Chien, E. K. 2005. Effects of selective and nonselective PGE2 receptor agonists on cervical tensile strength and collagen organization and microstructure in the pregnant rat at term. Am. J. Obstet. Gynecol. 192: 753-760. [Medline] [CrossRef]

7. Fosang, A. J., Hey, N. J., Carney, S. L. and Hardingham, T. E. 1990. An ELISA plate-based assay for hyaluronan using biotinylated proteoglycan G1 domain (HA-binding region). Matrix 10: 306-313. [Medline] [CrossRef]

8. Fosang, A. J., Handley, C. J., Santer, V., Lowther, D. A. and Thorburn, G. D. 1984. Pregnancy-related changes in the connective tissue of the ovine cervix. Biol. Reprod. 30: 1223-1235. [Medline] [CrossRef]

9. Golichowski, A. M., King, S. R. and Mascaro, K. 1980. Pregnancy-related changes in rat cervical glycosaminoglycans. Biochem. J. 192: 1-8. [Medline]

10. Goranova, V., Vizza, E. and Motta, P. M. 1993. Collagen fibrillar network in estrous and hCG-stimulated rabbit uterus: a SEM study after $\mathrm{NaOH}$ maceration. Arch. Histol. Cytol. 56: 231-241. [Medline] [CrossRef]

11. Hasler, E. M., Herzog, W., Wu, J. Z., Muller, W. and Wyss, U. 1999. Articular cartilage biomechanics: theoretical models, material properties, and biosynthetic response. Crit. Rev. Biomed. Eng. 27: 415-488. [Medline]

12. Junqueira, L. C., Zugaib, M., Montes, G. S., Toledo, O. M., Krisztan, R. M. and Shigihara, K. M. 1980. Morphologic and histochemical evidence for the occurrence of collagenolysis and for the role of neutrophilic polymorphonuclear leukocytes during cervical dilation. Am. J. Obstet. Gynecol. 138: 273-281. [Medline]

13. Kemp, B., Classen-Linke, I., Ruck, P., Winkler, M., Beier, H. M. and Rath, W. 1998. Cell populations in the human uterine cervix during midcyclic cervical opening. Geburtsh Frauenheilk 58: 547-550 (in German). [CrossRef]

14. Kershaw-Young, C. M., Khalid, M., McGowan, M. R., Pitsillides, A. A. and Scaramuzzi, R. J. 2009. The mRNA expression of prostaglandin E receptors EP2 and EP4 and the changes in glycosaminoglycans in the sheep cervix during the estrous cycle. Theriogenology 72: 251-261. [Medline] [CrossRef]

15. Kershaw, C. M., Scaramuzzi, R. J., McGowan, M. R., WheelerJones, C. P. and Khalid, M. 2007. The expression of prostaglandin endoperoxide synthase 2 messenger RNA and the proportion of smooth muscle and collagen in the sheep cervix during the estrous cycle. Biol. Reprod. 76: 124-129. [Medline] [CrossRef]

16. Kitamura, K., Ito, A., Mori, Y. and Hirakawa, S. 1980. Glycosaminoglycans of human uterine cervix: heparan sulfate increase with reference to cervical ripening. Biochem. Med. 23: 159-166. [Medline] [CrossRef]

17. Kjaer, M. 2004. Role of extracellular matrix in adaptation of tendon and skeletal muscle to mechanical loading. Physiol. Rev. 84: 649-698. [Medline] [CrossRef]

18. Kunkitti, P., Srisuwatanasagul, S. and Chatdarong, K. 2011. Distribution of estrogen receptor alpha and progesterone receptor, and leukocyte infiltration in the cervix of cyclic bitches and those with pyometra. Theriogenology 75: 979-987. [Medline] [CrossRef]

19. Meredith, M. J. 1977. Clinical examinations of the ovaries and cervix of the sow. Vet. Rec. 101: 70-74. [Medline] [CrossRef]

20. Obrink, B. 1973. The influence of glycosaminoglycans on the 
formation of fibers from monomeric tropocollagen in vitro. Eur. J. Biochem. 34: 129-137. [Medline] [CrossRef]

21. Osmers, R., Rath, W., Pflanz, M. A., Kuhn, W., Stuhlsatz, H. W. and Szeverenyi, M. 1993. Glycosaminoglycans in cervical connective tissue during pregnancy and parturition. Obstet. Gynecol. 81: 88-92. [Medline]

22. Owiny, J. R., Fitzpatrick, R. J., Spiller, D. G. and Appleton, J. 1987. Scanning electron microscopy of the wall of the ovine cervix uteri in relation to tensile strength at parturition. Res. Vet. Sci. 43: 36-43. [Medline]

23. Ponglowhapan, S., Church, D. B. and Khalid, M. 2011. Effect of the gonadal status and the gender on glycosaminoglycans profile in the lower urinary tract of dogs. Theriogenology $\mathbf{7 6}$ : 1284-1292. [Medline] [CrossRef]

24. Ponglowhapan, S., Church, D. B. and Khalid, M. 2010. Expression of prostaglandin E receptor subtypes in the canine lower urinary tract varies according to the gonadal status and gender. Theriogenology 74: 1450-1466. [Medline] [CrossRef]

25. Rath, W., Osmers, R., Stuhlsatz, H. W. and Adelmann-Grill, B. C. 1994. Biochemical principles of cervix ripening and dilatation. Z. Geburtshilfe Perinatol. 198: 186-195. [Medline]

26. Roughley, P. J. and Lee, E. R. 1994. Cartilage proteoglycans: structure and potential functions. Microsc. Res. Tech. 28: 385397. [Medline] [CrossRef]

27. Silva, L. D., Onclin, K. and Verstegen, J. P. 1995. Cervical opening in relation to progesterone and oestradiol during heat in beagle bitches. J. Reprod. Fertil. 104: 85-90. [Medline] [CrossRef]

28. Stringer, S. E. and Gallagher, J. T. 1997. Heparan sulphate. Int. J. Biochem. Cell Biol. 29: 709-714. [Medline] [CrossRef]

29. Takemura, M., Itoh, H., Sagawa, N., Yura, S., Korita, D., Kakui, K., Kawamura, M., Hirota, N., Maeda, H. and Fujii, S. 2005. Cyclic mechanical stretch augments hyaluronan production in cultured human uterine cervical fibroblast cells. Mol. Hum. Reprod. 11: 659-665. [Medline] [CrossRef]

30. Tamada, H., Kawata, N., Kawate, N., Inaba, T., Kida, K., Hatoya, S., Akune, A., Nakama, K., Kohsaka, T., Takahashi, M. and Sawada, T. 2012. Factors associated with patency of the uterine cervix in bitches with pyometra. Res. Vet. Sci. 93: 1203-1210. [Medline] [CrossRef]

31. Tanaka, K., Nakamura, T., Takagaki, K., Funahashi, M., Saito, Y. and Endo, M. 1997. Regulation of hyaluronate metabolism by progesterone in cultured fibroblasts from the human uterine cervix. FEBS Lett. 402: 223-226. [Medline] [CrossRef]

32. Tsiligianni, T. H., Karagiannidis, A., Brikas, P. and Saratsis, P. H. 2001. Chemical properties of bovine cervical mucus during normal estrus and estrus induced by progesterone and/or PGF2alpha. Theriogenology 56: 41-50. [Medline] [CrossRef]

33. Uchiyama, T., Sakuta, T. and Kanayama, T. 2005. Regulation of hyaluronan synthases in mouse uterine cervix. Biochem. Biophys. Res. Commun. 327: 927-932. [Medline] [CrossRef]

34. Uldbjerg, N., Ekman, G., Malmstrom, A., Olsson, K. and Ulmsten, U. 1983. Ripening of the human uterine cervix related to changes in collagen, glycosaminoglycans, and collagenolytic activity. Am. J. Obstet. Gynecol. 147: 662-666. [Medline]

35. Van Kuppevelt, T. H., Rutten, T. L. and Kuyper, C. M. 1987. Ultrastructural localization of proteoglycans in tissue using cuprolinic blue according to the critical electrolyte concentration method: comparison with biochemical data from the literature. Histochem. J. 19: 520-526. [Medline] [CrossRef]

36. Vanhoutte, D., Schellings, M. W., Gotte, M., Swinnen, M., Herias, V., Wild, M. K., Vestweber, D., Chorianopoulos, E., Cortes, V., Rigotti, A., Stepp, M. A., Van de Werf, F., Carmeliet, P., Pinto, Y. M. and Heymans, S. 2007. Increased expression of syndecan-1 protects against cardiac dilatation and dysfunction after myocardial infarction. Circulation 115: 475-482. [Medline] [CrossRef]

37. Winkler, M. and Rath, W. 1999. Changes in the cervical extracellular matrix during pregnancy and parturition. J. Perinat. Med. 27: 45-60. [Medline] [CrossRef]

38. Zhang, Q., Collins, V., Chakrabarty, K., Rose, J. C. and Wu, W. X. 2007. Regulation of the prostaglandin enzymatic system by estradiol and progesterone in nonpregnant sheep cervix. Reproduction 133: 1027-1034. [Medline] [CrossRef] 